\title{
How to deal with cryptic species in Enchytraeidae, with recommendations on taxonomical descriptions
}

\author{
R.M. SCHMElZ ${ }^{1,2}$, A. BeYlich ${ }^{3 *}$, G. BOROS ${ }^{4 *}$, K. DÓZSA-FARKAS ${ }^{5 *}$, U. GRAEFE $^{6 *}$ \\ Y. HONG $^{7 *}$, J. RÖMBKE $^{8 *}$, J. SCHLAGHAMERSKÝ $^{9 *}$, S. MARTINSSON ${ }^{10 \propto}$ \\ ${ }^{1}$ Rüdiger M. Schmelz, ECT Ökotoxciologie GmbH, Böttgerstr. 2-14, 65439 Flörsheim, Germany. \\ Email:rmschmelz@gmail.com \\ ${ }^{2}$ University of A Coruña, Science Faculty, GIBE, Evolutionary Biology Research Group, CICA, As \\ Carballeiras s/n, Campus de Elviña, 15071 A Coruña, Spain \\ ${ }^{3}$ Anneke Beylich, IFAB Institute for Applied Soil Biology GmbH, Tornberg 24a, 22337 Hamburg, \\ Germany \\ ${ }^{4}$ Gergely Boros, MTA Centre for Ecological Research, Klebelsberg Kuno u. 3, H-837 Tihany, Hungary \\ ${ }^{5}$ Klára Dózsa-Farkas, Eötvös Loránd University, Department of Systematic Zoology and Ecology, \\ Pázmány Péter sétány 1/C,H-1117 Budapest, Hungary. \\ ${ }^{6}$ Ulfert Graefe IFAB Institute for Applied Soil Biology GmbH, Tornberg 24a, 22337 Hamburg, Germany \\ ${ }^{7}$ Yong Hong, Department of Agricultural Biology, College of Agriculture \& Life Science, Chonbuk \\ National University, Jeonju, Republic of Korea \\ ${ }^{8}$ Jörg Römbke, ECT Ökotoxiologie GmbH, Böttgerstr. 2-14, 65439 Flörsheim, Germany \\ ${ }^{9}$ Jiri Schlaghamerský, Department of Botany and Zoology, Faculty of Science, Masaryk University, Brno, \\ Czech Republic \\ ${ }^{10}$ Svante Martinsson, Department of Biological and Environmental Sciences, University of Gothenburg, \\ Box 463, SE-405 30 Göteborg, Sweden.E-mail: svante.martinsson@bioenv.gu.se, svante880@gmail.com \\ ${ }^{*}$ Co-authors contributed equally ${ }^{\circ}$ Corresponding author
}

\begin{abstract}
During the 12th International Symposium on Enchytraeidae, held in Tihany, Hungary (27-29 June 2016), the participants discussed cryptic species, i.e., species that are morphologically so similar that they are classified as the same species (Bickford et al. 2007), and how to deal with them taxonomically. Here we summarise the discussion together with a few additional comments, and we give recommendations for species descriptions in Enchytraeidae.
\end{abstract}

Keywords. Annelids, morphospecies, sequencing.

\section{INTRODUCTION}

$\mathrm{S}^{\mathrm{r}}$ pecies are basic biological units, and the first step in the exploration of biodiversity. Species are also entities of generalisation: information from different studies of individuals of the same species can be generalised to that species, but not necessarily for a more inclusive taxon, e.g., a genus or a family. However, for this generalisation it is important that the specimens are correctly identified to species, and species are correctly delimited, to avoid, for example, that several species differing in various properties, e.g. ecological or physiological, are included under the same name. Both correct identification of previously named species, and the naming and description of new taxa are crucial steps for describing the biota of the world, and also to ensure that scientists mean the same thing when using a species name. Taxonomic names are also needed to link species to data, produced in different studies, so that they can be related in various analyses. If data (e.g. ecological, morphological, and molecular) cannot be linked to formal species 
and well-referenced names, these data will lose much of their value. The proper naming and description of species is therefore essential.

Enchytraeids have traditionally been studied alive using light microscopy, and the morphological investigation of whole worms, either alive or fixed, is still the basis for the identification of specimens and descriptions of new species. However, with the introduction of widely accessible molecular methods, notably the sequencing of DNA 'barcode' fragments and refined analytical tools, a new standard set of data has become available to recognize and to delimit species. DNA sequences often confirmed the distinctions drawn between morphologically defined species (Klinth et al. 2017, De Wit \& Erséus 2010), but in some cases they showed that species described on the basis of morphological differences are in fact synonyms (Dózsa-Farkas et al. 2012). More importantly, they also revealed the existence of cryptic species, i.e. species that, so far, cannot be differentiated with morphology-based methods (Martinsson \& Erséus 2014, Matamoros et al. 2012).

It is important to note that cryptic species have been known in enchytraeids for more than half a century, based on karyology (Christensen 1961), protein patterns (Brockmeyer 1991, Christensen et al. 1992, Schmelz 2003, Westheide \& Graefe 1992) or other techniques, but they were never formally recognized and described, with the notable exception of Enchytraeus crypticus Westheide \& Graefe, 1992. A list in Collado et al. (2012) contains 40 enchytraeid species as candidates for species complexes; they include almost all commonly cited species. Formal recognition of cryptic species has increased with the establishment of DNA sequencing as standard taxonomic method. There are currently four described truly cryptic species-pairs in Enchytraeidae (Table 1) and we expect many more to come. Cryptic species cannot be distinguished using the traditional and widely-used method of studying the morphology using light microscopy. Therefore, a discussion on how cryptic species should be treated was held during the symposium.
During the discussion, the participants agreed that cryptic species are distinct evolutionary lineages, which deserve recognition in a classificatory system. There is a growing body of evidence that cryptic species may differ in ecological and physiological properties, and therefore the separation of cryptic lineages within morphospecies can be important when such species are used as models in ecology, ecotoxicology and physiology (see Feckler et al. 2013, Römbke et al. 2016). ('Morphospecies' is used here to denote mainly named species, described and identified in the traditional way, using morphological characters. Our use differs from the one in ecology, where 'morphospecies' often means morphologically distinguishable but unnamed species of unknown identity.) It was also agreed that a morphospecies that comprises an assemblage of cryptic species still deserves recognition even though it cannot be considered, due to reproductive barriers within, as one biological species any more. The reasons are not only practical but also biological: The assemblage of cryptic species (i.e. the morphospecies) may form a monophyletic group and may have common ecological properties that are different from the rest of the species in the genus. Morphospecies that turn out to be polyphyletic assemblages, however, should be abandoned. It should be noted that this consensual opinion differs from previous practice, where either the cryptic species or the morphospecies was discarded (Christensen 1961, Sturmbauer et al. 1999, Gustafsson et al. 2009, James et al. 2010).

However, opinions differed as to how cryptic lineages should be recognised. Two options included the use of informal categories:

- Maintain the species name of the morphospecies and denote the cryptic species appending a series of alphanumerical codes to the name of the morphospecies;

- Give full species rank to the cryptic species and denote the morphospecies with the old name plus an epitheton like "sensu lato", or "species group" or "species complex". 
Table 1. Cryptic species pairs in Enchytraeidae. Included are also species pairs with morphological differences inconclusive or difficult to access.

\begin{tabular}{|c|c|c|c|}
\hline & Habitat & Type of difference & Morphological differences \\
\hline $\begin{array}{l}\text { Enchytraeus variatus Bouguenec } \\
\text { \& Giani, } 1987 \\
\text { Enchytraeus crypticus Westheide } \\
\text { \& Graefe, } 1992\end{array}$ & $\begin{array}{l}\text { compost, } \\
\text { soil }\end{array}$ & $\begin{array}{l}\text { Isozyme patterns, total protein } \\
\text { patterns (Brockmeyer 1991) } \\
\text { DNA-RFLPs (Schlegel et al. 2009) } \\
\text { CIE, crossed immuno- } \\
\text { electrophoresis (Gabrich et al. 1991) } \\
\text { RAPD-PCR (Schirmacher et al. } \\
\text { 1998) }\end{array}$ & $\begin{array}{l}\text { Ultrastructure of spermatozoa } \\
\text { (Westheide et al. 1991) }\end{array}$ \\
\hline $\begin{array}{l}\text { Grania bekkouchei Prantoni, De } \\
\text { Wit \& Erséus, } 2016 \\
\text { Grania cryptica Prantoni, De Wit } \\
\text { \& Erséus, } 2016\end{array}$ & $\begin{array}{l}\text { marine } \\
\text { sediment }\end{array}$ & $\begin{array}{l}\text { DNA sequences (Prantoni et al. } \\
\text { 2016) }\end{array}$ & none \\
\hline $\begin{array}{l}\text { Chamaedrilus/Cognettia* } \\
\text { sphagnetorum (Vejdovský, 1878) } \\
\text { Chamaedrilus } \\
\text { pseudosphagnetorum Martinsson, } \\
\text { Rota \& Erséus, 2015a }\end{array}$ & soil & $\begin{array}{l}\text { DNA sequences (Martinsson and } \\
\text { Erséus 2014, Martinsson et al. } \\
\text { 2015b) }\end{array}$ & none \\
\hline $\begin{array}{l}\text { Grania ovitheca Erséus, } 1977 \\
\text { Grania occulta De Wit \& Erséus, } \\
2010\end{array}$ & $\begin{array}{l}\text { marine } \\
\text { sediment }\end{array}$ & $\begin{array}{l}\text { DNA sequences (De Wit and Erséus } \\
\text { 2010) }\end{array}$ & none \\
\hline $\begin{array}{l}\text { Enchytraeus bigeminus Nielsen \& } \\
\text { Christensen, } 1963 \\
\text { Enchytraeus japonensis } \\
\text { Nakamura, } 1993\end{array}$ & $\begin{array}{l}\text { compost, } \\
\text { soil }\end{array}$ & $\begin{array}{l}\text { Isozyme patterns, Total protein } \\
\text { patterns (Schmelz et al. 2000) }\end{array}$ & $\begin{array}{l}\text { Male sexual glands (species } \\
\text { with predominantly asexual } \\
\text { repoduction) (Schmelz et al. } \\
2000 \text { ) }\end{array}$ \\
\hline $\begin{array}{l}\text { Chamaedrilus/Cognettia } \\
\text { glandulosus (Michaelsen, 1888) } \\
\text { Chamaedrilus varisetosus } \\
\text { Martinsson \& Erséus, 2015b }\end{array}$ & $\begin{array}{l}\text { soil, } \\
\text { aquatic } \\
\text { sediments }\end{array}$ & $\begin{array}{l}\text { DNA sequences (Martinsson and } \\
\text { Erséus 2014, Martinsson et al. } \\
\text { 2015a) }\end{array}$ & $\begin{array}{l}\text { Body size, chaetal numbers } \\
\text { (Martinsson et al. 2015a) }\end{array}$ \\
\hline
\end{tabular}

* Priority of Cognettia or Chamaedrilus awaits ruling by the International Commission on Zoological Nomenclature, see http://www.iczn.org, Case 3689.

Two further options excluded informal categories and promoted the integration of the taxic diversity into the Linnaean system:

- Maintain the species rank for the morphospecies and use the subspecies rank for the cryptic species.

- Give full species rank for the cryptic species and a supraspecific rank (e.g., subgenus), for the morphospecies.

All of these options have their pros and cons. Using the morphospecies with an alphanumerical code to represent the different cryptic lineages will let us continue using the morphospecies as taxonomical units in inventories, species lists etc., but there is the risk that the knowledge about the cryptic lineages is ignored, as they are not formally recognised and described taxa. Whereas if cryptic lineages were formally described as species, identification of specimens to species based on morphology would become impossible, and specimens could only be identified to species groups or species "sensu lato". However, the cryptic lineages would at least be recognised as species, and could thereby be included in counts of biodiversity and be seen as different units. A drawback of this option is the possible confusion caused by the same name used with two different meanings, either sensu lato (morphospecies) and sensu stricto (cryptic species).

Informal ranks and categories have the advantage of being flexible but the disadvantage of not being regulated, which may promote confusion in the meaning of names; they should therefore be considered only as an interim solution. The preferable full integration of the diversity into the 
Linnaean system of names, however, faces other problems: The use of the subspecies category for cryptic species would contradict the traditional concept of subspecies as morphologically distinguishable populations of a species that replace each other geographically (Mallet 2007). In fact, cryptic species fulfil all criteria of being 'species', regardless which species concept is applied here (Bickford et al. 2007). On the other hand, a rank elevation of morphospecies to subgenus level would create considerable classificatory and nomenclatural instability: First, it would necessitate a complete reorganization of the classificatory architecture of a genus, because the subgeneric category cannot be applied selectively and hence affects all species of a genus. Second, each morphospecies elevated to subgeneric rank (the type species of the genus excepted) would need a new subgeneric name. The same problems would arise, mutatis mutandis, with the elevation of morphospecies to genus rank. To conclude, solutions to this classificatory problem are not straightforward and may differ from case to case.

Another important question is what evidence at the level of genetic markers is necessary to decide whether specimens belong to the same species or to different species, and whether a species is undescribed or not. Traditionally the characters used are morphological, both external and internal, but molecular data are becoming more and more common as the base for taxonomical decisions. Also ecological and physiological data, if available, can aid in the species delimitation process. The most commonly available genetic marker is the mitochondrial gene cytochrome $\mathrm{C}$ subunit I (COI) that is used as the barcode for animals (Hebert et al. 2003). However, if used alone, COI will often overestimate the number of species, and it should be used with caution and in combination with other data (Dasmahapatra et al. 2010). As a broad rule of thumb, in clitellates, if two cluster differ with more than $10 \%$ uncorrected genetic distance, i.e., if more than $10 \%$ of the nucleotides differ between the two lineages, they are likely to belong to different species, and if they differ with less than 5\% they are likely to belong to one species (Rougerie et al. 2009, Römbke et al. 2016, but see Giska et al. 2015,
Martinsson \& Erséus 2017 for exceptions). More support is, however, needed in order to make a robust delimitation. Other commonly used markers are the nuclear Histone $\mathrm{H} 3(\mathrm{H} 3)$ and the ribosomal internally transcribed spacer region (ITS) consisting of ITS1, 5.8S and ITS2. H3 has been recommended as a secondary barcode for Enchytraeidae (Schmelz et al. 2014), and both H3 and ITS have good discriminatory power and will in most cases separate closely related species.

A third problem with cryptic species was discussed at the symposium: When cryptic species are detected within a morphospecies and are described formally according to nomenclatural rules (ICZN 1999), one lineage should bear the name of the morphospecies, notably the one to which the name-bearing type of the morphospecies belongs. However, finding the correct lineage may be difficult because type material is lost or in a state of preservation that does not allow extraction of DNA; both cases are very common in enchytraeids. A possible solution is to get fresh material from the type locality for sequencing, and in that way tie the name to a genetic lineage. However, in many cases the type localities are vague or missing; in these cases it should be sufficient to use material from the wider area where it can be supposed that the original material was collected. As a further complication, however, more than one cryptic lineage may be present at the type locality or in the wider area. To conclude, the choice of the name-bearing lineage is often a decision based on probabilities, and the task is to raise the probability-level as much as possible. For example, in case that small morphological differences exist between the candidate lineages, the one that fits the original description best should be chosen to bear the name of the old morphospecies. If uncertainty is too high, there remains the radical solution of dismissing the old name as "nomen dubium".

\section{RECOMMENDATIONS}

Based on the consensus that both morphological characters and molecular markers are important for species-level taxonomy in enchytraeids, we recommend: 
1. The erection of new species should include a good morphological description with illustrations of the important taxonomic characters and also a reference to molecular markers that are informative at the species level: at least one, but preferably two markers, one being mitochondrial (e.g., COI), one nuclear (e.g., ITS, H3).

2. DNA sequences should be generated from at least one of the type specimens, preferably the holotype or a syntype specimen, to link the sequence permanently with the name. However, some of the paratypes and other reference specimens should also be sequenced to avoid errors and to allow estimates of variability.

3. When species are erected based on only one set of data (i.e., either morphological characters alone or DNA sequences alone), the retrieval of missing or additional data should be made possible by appropriate fixation and preservation of at least some specimens of the type series. This means, for DNA, at the present state of knowledge, the use of ethanol as preservation liquid at concentrations higher than $70 \%$.

4. Sequencing is also recommended in specimens that form the basis of redescriptions and in those that are elected as neotypes in taxonomic revisions.

5. Of each sequenced specimen, the anterior part of the animal should be retained as a voucher and deposited in a public collection. (In enchytraeids, most of the taxonomically informative structures are located in the anterior body part.)

We understand that it will not always be possible to extract and sequence DNA from the specimens used as the basis for a new species description, e.g., due to fixation methods, old age and bad storage or due to other factors, but whenever possible we recommend that DNA-sequence-data should be included in future descriptions of enchytraeids.

Acknowledgements -We thank the participants of the $12^{\text {th }}$ International Symposium on Enchytraeidae (Tihany,
Hungary (27-29 June 2016)) for their contributions when discussing this issue.

\section{REFERENCES}

BICKFORD, D., LOHMAN, D.J., SODHI, N.S., NG, P.K., MEIER, R., WinKer, K., INGRAM, K.K. \& DAS, I. (2007): Cryptic species as a window on diversity and conservation. Trends in Ecology \& Evolution, 22: 148-155. doi: 10.1016/j.tree.2006.11.004

BROCKMEYER, V. (1991): Isozymes and general protein patterns for use in discrimination and identification of Enchytraeus species (Annelida, Oligochaeta). Zeitschrift für zoologische Systematik und Evolutionsforschung, 29: 343-361. doi: 10.1111/j.1439-0469.1991.tb00457.x

Christensen, B. (1961): Studies on Cyto-Taxonomy and Reproduction in the Enchytraeidae. Hereditas, 47: 387-450. doi: 10.1111/j.1601-5223.1961.tb01782.x

Christensen, B., Hvilsom, M. \& Pedersen, B.V. (1992): Genetic variation in coexisting sexual diploid and parthenogenetic triploid forms of Fridericia galba (Enchytraeidae, Oligochaeta) in a heterogeneous environment. Hereditas, 117: 153-162. doi: 10.1111/j.1601-5223.1992.tb00169.x

Collado, R., Hass-Cordes, E. \& Schmelz, R.M. (2012): Microtaxonomy of fragmenting Enchytraeus species using molecular markers, with a comment on species complexes in enchytraeids. Turkish Journal of Zoology, 36: 85-94. doi: 10.3906/zoo-1002-70

DASMAHAPATRA, K.K., Elias, M., Hill, R.I., HofFMAN, J.I. \& MALLET, J. (2010): Mitochondrial DNA barcoding detects some species that are real, and some that are not. Molecular Ecology Resources, 10: 264-273. doi: 10.1111/j.1755-0998.2009.02763.x

DE WIT, P. \& ERSÉUS, C. (2010): Genetic variation and phylogeny of Scandinavian species of Grania (Annelida: Clitellata: Enchytraeidae), with the discovery of a cryptic species. Journal of Zoological Systematics and Evolutionary Research, 48: 285293. doi: 10.1111/j.1439-0469.2010.00571.x

Dózsa-Farkas, K., Porco, D. \& Boros, G. (2012): Are Bryodrilus parvus Nurminen, 1970 and Bryodrilus librus (Nielsen and Christensen, 1959) (Annelida: Enchytraeidae) really different species? A revision based on DNA barcodes and morphological data. Zootaxa, 3276: 38-50. 
FeCKler, A., Schulz, R. \& Bundschuh, M. (2013): Cryptic lineages-same but different? Integrated Environmental Assessment and Management, 9: 172-173. doi: 10.1002/ieam.1370

GABrich, A., JAROS, P.P. \& BROCKMAYER, V. (1991): Application of immunological methods for the taxonomic study of two selected animal taxa: Tisbe (Crustacea, Copepoda) and Enchytraeus (Annelida, Oligochaeta). Zeitschrift für zoologische Systematik und Evolutionsforschung, 29: 381-392.

GiskA, I., SECHI, P. \& BABIK, W. (2015): Deeply divergent sympatric mitochondrial lineages of the earthworm Lumbricus rubellus are not reproductively isolated. BMC Evolutionary Biology, 15: 217. doi: 10.1186/s12862-015-0488-9

Gustafsson, D.R., Price, D. A. \& Erséus, C. (2009): Genetic variation in the popular lab worm Lumbriculus variegatus (Annelida: Clitellata: Lumbriculidae) reveals cryptic speciation. Molecular Phylogenetics and Evolution, 51: 182-189. doi: 10.1016/j.ympev.2008.12.016

Hebert, P.D., CYWINSKA, A., BALl, S.L. \& DeWAARD, J.R. (2003): Biological identifications through DNA barcodes. Proceedings of the Royal Society Biological Sciences Series B, 270: 313-321. doi: 10.1098/rspb.2002.2218

ICZN (1999): International Code of Zoological Nomenclature, London, The International Trust for Zoological Nomenclature.

James, S.W., Porco, D., Decaens, T., Richard, B., ROUGERIE, R. \& ERSÉUS, C. (2010): DNA barcoding reveals cryptic diversity in Lumbricus terrestris L., 1758 (Clitellata): resurrection of $L$. herculeus (Savigny, 1826). PLoS ONE, 5: e15629. doi: 10.1371/journal.pone.0015629

Klinth, M. J., Martinsson, S. \& ERsÉUs, C. (2017): Phylogeny and species delimitation of North European Lumbricillus (Clitellata, Enchytraeidae). Zoologica Scripta, 46: 96-110. doi: $10.1111 /$ zsc. 12187

Mallet, J. (2007): Subspecies, semispecies, superspecies. In. LEVIN, D.A. (Ed.) Encyclopedia of Biodiversity. vol 5, Online update 1,. Oxford, Elsevier.

Martinsson, S. \& ERsÉus, C. (2014): Cryptic diversity in the well-studied terrestrial worm Cognettia sphagnetorum (Clitellata: Enchytraeidae). Pedobiologia, 57: 27-35. doi: 10.1016/j.pedobi.2013.09.006
MARTINSSON, S. \& ERSÉUS, C. (2017): Cryptic speciation and limited hybridization within Lumbricus earthworms (Clitellata: Lumbricidae). Molecular Phylogenetics and Evolution, 106: 18-27. doi: 10.1016/j.ympev.2016.09.011

Martinsson, S., Rota, E. \& ERsÉUs, C. (2015a): On the identity of Chamaedrilus glandulosus (Michaelsen, 1888) (Clitellata, Enchytraeidae), with the description of a new species. Zookeys, 501: 1-14. doi: 10.3897/zookeys.501.9279

Martinsson, S., Rota, E. \& ERsÉUs, C. (2015b): Revision of Cognettia (Clitellata, Enchytraeidae): reestablishment of Chamaedrilus and description of cryptic species in the sphagnetorum complex. Systematics and Biodiversity, 13: 257-277. doi: 10.1080/14772000.2014.986555

Matamoros, L., Rota, E. \& ERsÉUs, C. (2012): Cryptic diversity among the achaetous Marionina (Annelida, Clitellata, Enchytraeidae). Systematics and Biodiversity, 10: 509-525. doi: 10.1080/14772000.2012.723640

Prantoni, A.L., De WIT, P. \& ERsÉus, C. (2016): First reports of Grania (Clitellata: Enchytraeidae) from Africa and South America: molecular phylogeny and descriptions of nine new species. Zoological Journal of the Linnean Society, 176: 485-510. doi: 10.1111/zoj.12333

Rougerie, R., Decaëns, T., Deharveng, L., Porco, D., James, S.W., Chang, C.-H., Richard, B., POTAPOV, M., SUHARDJONO, Y. \& HEBERT, P.D.N. (2009): DNA barcodes for soil animal taxonomy. Pesquisa Agropecuaria Brasileira, 44: 789-802. doi: 10.1590/S0100-204X2009000800002

RÖMBKe, J., AIRA, M., BACKELJAU, T., BREUGELMANS, K., Domínguez, J., Funke, E., Graf, N., HaJIBABAEI, M., PÉREZ-LOSADA, M., PORTO, P.G., SCHMELZ, R.M., VIERNA, J., VIZCAÍNO, A. \& PFENNINGER, M. (2016): DNA barcoding of earthworms (Eisenia fetida/andrei complex) from 28 ecotoxicological test laboratories. Applied Soil Ecology, 104: 3-11. doi: 10.1016/j.apsoil.2015.02.010

Schirmacher, A., Schmidt, H. \& Westheide, W. (1998): RAPD-PCR investigations on sibling species of terrestrial enchytraeus (Annelida: Oligochaeta). Biochemical Systematics and Ecology, 26: 35-44.

SChlegel, M., SteinbrÜCK, G., KrAMER, M. \& BROCKMEYER, V. (2009): Restriction fragment 
patterns as molecular markers for species identification and phylogenetic analysis in the genus Enchytraeus (Oligochaeta)1. Journal of Zoological Systematics and Evolutionary Research, 29: 362372. doi: 10.1111/j.1439-0469.1991.tb00458.x

SCHMELZ, R.M. (2003): Taxonomy of Fridericia (Oligochaeta, Enchytraeidae). Revision of species with morphological and biochemical methods. Abhandlungen des Naturwissenschaftlichen Vereins in Hamburg (Neue Folge), 38: 1-415 + 37 Figs.

Schmelz, R. M., Collado, R. \& MyOhara, M. (2000): A Taxonomic Study of Enchytraeus japonensis (Enchytraeidae, Oligochaeta): Morphological and Biochemical Comparisons with $E$. bigeminus. Zoological Science, 17: 505-516. doi: 10.2108/0289-0003(2000)17[505:atsoej]2.0.co;2

Schmelz, R. M., Vierna, J., Vizcaino, A., Perina, A., Collado, R. \& RömbKe, J. (2014): Two are better than one: $\mathrm{COI}$ and $\mathrm{H} 3$ as DNA barcodes for enchytraeids. Poster presented at: 10th International Symposium on Earthworm Ecology, June 22-27, 2014, Athens, Georgia, USA

Sturmbauer, C., OpAdiya, G.B., Niederstätter, H., RiedmanN, A. \& DALlinger, R. (1999): Mitochondrial DNA reveals cryptic oligochaete species differing in cadmium resistance. Molecular Biology and Evolution, 16: 967-974.

Westheide, W. \& GRAEFE, U. (1992): Two new terrestrial Enchytraeus species (Oligochaeta, Annelida). Journal of Natural History, 26: 479-488. doi: 10.1080/00222939200770311

Westheide, W., Purschke, G. \& Middendorf, K. (1991): Spermatozoal ultrastructure of the taxon Enchytraeus (Annelida, Oligochaeta) and its significance for species discrimination and identification. Zeitschrift für zoologische Systematik und Evolutionsforschung, 29: 323-342. doi: 10.1111/j.1439-0469.1991.tb00456.x 